\title{
CARACTERÍSTICAS SONORAS EN LOS TRÁILERES CINEMATOGRÁFICOS
}

Francesc Llinares Heredia1: Universidad de Barcelona. España.

fllinares@ub.edu

Diego Calderón Garrido: Universidad de Barcelona. España.

dcalderon@ub.edu

Josep Gustems Carnicer: Universidad de Barcelona. España.

jgustems@ub.edu

\section{RESUMEN}

El tráiler cinematográfico representa el primer acercamiento a una película incluso antes de que esté rodada. En él, se mezclan hábilmente elementos cinematográficos y promocionales. Por su corta duración y su montaje discontinuo, la música ejerce de hilo conductor, dándole coherencia y continuidad. El presente estudio busca extraer las similitudes y diferencias sonoras existentes en función del género cinematográfico de la película que cada tráiler promociona. De esta forma, y a través de la aplicación de una ficha de análisis diseñada $a d$ hoc a un total de 50 tráileres de films estrenados durante el año 2013, observamos como los diseñadores y montadores de tráileres combinan las características estilísticas, rítmicas, melódicas del sonido y la música con una clara intención emocional.

\section{PALABRAS CLAVE}

Tráiler - Música - Sonido - Cine - Comunicación audiovisual - Publicidad

\section{SOUND CHARACTERISTICS ON FILM TRAILERS}

\section{ABSTRACT}

The movie trailer is the first approach to a film even before it is filmed. In it, film and promotional items are skillfully mixed. For its short duration and discontinuous editing, music acts as thread, giving coherence and continuity. This study try to

\footnotetext{
${ }^{1}$ Farncesc Llinares Heredia: Licenciado en Historia del Arte y especialista en informática musical, es profesor de música en secundaria y de música y sonido en Comunicación Audiovisual en la Universidad de Barcelona.
} 
extract the similarities and differences in terms of sound depending on the film genre of the movie that promotes each trailer.

In this way, and through the application of an analysis card designed ad hoc to a total of 50 trailers films premiered in 2013, we observed that designers and trailers assemblers combine the stylistic, rhythmic and melodic characteristics of the sound and music with a clear emotional intent.

\section{KEY WORDS}

Trailer - Music - Sound - Cinema - Audiovisual comunication - Publicity

\section{INTRODUCCIÓN}

No cabe duda de que un alto porcentaje de la venta o consumo de un producto depende de la publicidad que le acompañe, sea ésta del tipo que sea. Dicha publicidad busca, en la mayoría de los casos, trazar puentes emocionales entre el producto y la posible persona que ha de disfrutarlo. En estos puentes el ambiente sonoro resulta de vital importancia debido a la ayuda que éste ofrece, tanto en la carga emotiva que los consumidores reciben como en la ayuda que presta a la hora de organizar el discurso visual. En este sentido, los tráileres guardan muchas similitudes con los spots publicitarios, por lo que es de vital importancia conocer el uso que en ellos se hace de la música y el sonido. Además, cada genero cinematográfico está envuelto por una serie de sonidos, estilos musicales, instrumentaciones, etc. que lo caracterizan, los cuales pueden estar o no presentes igualmente en cada uno de los tráileres.

\subsection{El tráiler como objeto de seducción}

Podemos definir un tráiler como un avance publicitario de una duración inferior a tres minutos y que tiene por finalidad promocionar una película (Dornaleteche, 2007). Por tanto y partiendo de esta definición, el objetivo del tráiler es seducir y cautivar al público provocando en éste el deseo de ver la película que el tráiler promociona. A pesar de su función esencialmente publicitaria, el tráiler, a menudo, ultrapasa ésta considerándose como una obra que se divulga por si misma y no una mera pieza divulgativa de una película (Iuva, 2010).

La técnica de montaje es de vital importancia en el acabado de una película y también, por supuesto, en la realización de un tráiler que, debido a su corta duración, implica un montaje rápido y discontinuo, combinando secuencias de diferentes partes de la película y utilizando recursos como por ejemplo la elipsis encaminados a la reducción temporal.

Murch (2003), quien considera que sugerir siempre es más eficaz que mostrar, al hablar del montaje cinematográfico plantea una cuestión: ¿Cómo queremos que se sienta el espectador? Ya que, según él, lo que recuerda el espectador al final de una 
película no es el montaje, ni el trabajo de la cámara, ni la interpretación, ni siquiera el argumento, sino cómo se ha sentido. Esto mismo lo podemos extrapolar al tráiler.

Para conseguir persuadir al espectador, normalmente el tráiler genera un horizonte de expectativas al mismo tiempo que le ofrece una importante carga emotiva en un breve espacio de tiempo y es, precisamente, en ese plano emotivo, donde el sonido y principalmente la música tienen un importante papel generando sensación de unidad y coherencia en el discurso narrativo y elaborando una atmósfera y un estilo que permita encuadrar la película en un determinado género cinematográfico.

Para lograr esto, Murch propone seguir lo que él llama la "regla del seis" que establece que un plano ideal es el que satisface los siguientes seis criterios: Emoción, Argumento, Ritmo, Dirección de la mirada, Plano bidimensional de la pantalla y Espacio tridimensional de la acción, destacando claramente la emoción por encima de los otros cinco criterios. En dichos ítems, la música y el sonido, o la ausencia de estos, juegan un papel vital, tal como veremos más adelante.

En cualquier caso, el montaje de un tráiler se realiza con un planteamiento diferente al de una película. En este sentido tenemos que tener claro que en el primero resulta básica la emoción que se transmite, sea esta del tipo que sea. Para conseguirlo se seleccionan y combinan las imágenes priorizando atraer la atención del espectador en detrimento del mantenimiento de la coherencia narrativa. La carga emotiva a la que hemos hecho referencia está acentuada y arropada por el sonido y la música, siendo ambos elementos los que se encargan de seducir y cautivar al espectador.

Además de lo descrito hasta ahora, debemos tener en cuenta de que no todos los tráileres cinematográficos son iguales, ya que estos dependen del medio en que se proyecte, de su duración, del tipo de montaje empleado y de la etapa en que se encuentra la realización de la película promocionada. Así por ejemplo, Dornaleteche (2007) propone una clasificación según las características formales de los tráileres, distinguiendo entre el teaser trailer (tráiler incitador) el cual es el primero que se exhibe de cara al público con una duración que, normalmente, no supera el minuto y medio; el creative trailer (tráiler creativo) que utiliza un material creado para tal efecto y no el de la película que promociona; el clip trailer (tráiler fragmento) que consiste en la emisión de un fragmento íntegro de la película que se quiere promocionar; el theatrical trailer (tráiler de cine) que es el más conocido y habitual en las salas de cine; el TV trailer (tráiler de televisión) que se inserta en los espacios publicitarios televisivos con una duración entre 15 y 30 segundos; y por último el denominado behind the scenes trailer (tráiler detrás de las cámaras) que muestra imágenes y secuencias de cómo se hizo la película. Además de esta clasificación, podemos añadir otras tipologías más recientes, como el tráiler de Internet, el cual se realiza de forma exclusiva para dicho medio (Llinares, 2014).

Aparte de esta diferenciación descrita, no cabe duda de que debemos atender a las diferentes tipologías de películas, las cuales, como resulta lógico, conllevan diferentes tipos de tráileres. De esta forma, y realizando una clasificación genérica la cual 
usaremos más adelante, podemos distinguir entre las películas de acción, las comedias o películas de humor, y las películas de terror (Marimón, 2014).

\subsection{Música y sonido en los tráileres}

Los elementos sonoros que se pueden encontrar en un tráiler son los mismos que forman parte de una película: voz - ya sea en forma de diálogos o de voz en off -, efectos sonoros, música y silencio. No obstante, a menudo el montaje del tráiler se realiza sin contar con los elementos sonoros que formarán parte de la película (música, efectos sonoros...), ya sea porque estos elementos aún no han sido creados o porque no se adecuan totalmente a la duración y ritmo que ha de tener el tráiler.

Además de los efectos sonoros realistas que se puedan utilizar en un tráiler encontramos efectos de sonido con la única intención de complementar y realzar la música maximizando, de esta manera, el impacto sensorial del tráiler y contribuyendo a la formación de la estructura del mismo enfatizando momentos claves, transiciones, frases, y títulos para crear un mayor impacto dramático.

Aunque la acción y los diálogos pueden ser parte fundamental del tráiler, normalmente su enfoque es mucho más musical que el de la película pues, en un tiempo tan breve, el ritmo, la tonalidad, la modalidad y la musicalidad en general tienen un cometido esencial en la percepción del mensaje por parte del espectador. Podemos afirmar que la música es un ingrediente clave en el tráiler pues influye drásticamente en la forma en que éste se percibe (Llinares, 2014).

En cualquier caso, la música que acompaña las imágenes de un tráiler, habitualmente, no se corresponde a la música original de la película. La razón de dicha falta de correspondencia se atribuye a, tal como ya hemos descrito, que el montaje y ritmo del tráiler difiere del de la película, por lo que la música original no se adapta al nuevo ritmo. En ocasiones, esta diferencia entre las músicas se debe, simplemente que el tráiler se haya realizado con anterioridad a la música de la película.

Por estos motivos, la música de un tráiler puede ser de diversa procedencia: música original de la propia película, música original de otras películas, música de uso libre, música de compañías especializadas en crear "librerías" de música para tráileres (Inmediate, Sencit, Audiomachine...), música preexistente de estilos diversos o música compuesta de manera específica para el tráiler. En un mismo tráiler se pueden combinar músicas de diversa procedencia así como, en función del tipo de tráiler (theatrical, teaser, TV...) de una misma película es posible que se utilicen diferentes músicas.

Tal y como expresa el diseñador de sonido Bryan Jerden en diversas entrevistas el tráiler es como una máquina en la que todos sus engranajes han de trabajar juntos. A diferencia de lo que suele acontecer en la película, incluso el contenido visual ha de ser editado siguiendo el ritmo de la música, a modo de clip musical prevaleciendo el 
interés por captar la atención (Sedeño, 2012), y el diálogo que narra la historia debe estar respaldado por la convergencia entre la tonalidad de la música y del ambiente sonoro, así como la sensación que la música provoca (Llinares, 2014).

\section{OBJETIVOS}

El objetivo de este trabajo es analizar las similitudes y diferencias entre las músicas y sonidos que acompañan los tráileres de diversos géneros cinematográficos convencionales (comedia, acción, terror), con el objetivo de determinar qué estilos y ambientación sonora les caracterizan.

\section{METODOLOGÍA}

La metodología empleada parte de la dualidad cualitativa/cuantitativa a través de la interpretación de datos recogidos mediante una ficha de análisis creada ad hoc y aplicada a cincuenta tráileres de películas realizadas el año 2013.

La distribución de la muestra fue la siguiente: catorce tráileres enmarcados en el género de acción, dieciocho en el de comedia y dieciocho en el de terror.

La ficha diseñada para su análisis (adaptada de Gustems y Calderón, 2014) tiene dos ejes. En el horizontal hemos realizado una distribución temporal de forma que podamos reflejar los cambios que se producen. Por otro lado, el eje vertical, en el cual se presentan los elementos analizar, contiene los siguientes ítems:

\section{Género de la película. Acción, Comedia o Terror}

$>$ Audio

- Existencia o inexistencia de voz hablada, ya sea en forma de diálogos o de voz en off.

- Música

○ Timbres/instrumentación

- Intensidades

- Alturas, líneas melódicas

- Tempo y ritmo

- Estilo

- Existencia y tipo o inexistencia de efectos sonoros diegéticos o no diegéticos

Relación audio-imagen

- Música empática/no empática

- Funciones de la música

\section{RESULTADOS}

A continuación mostramos los resultados obtenidos al aplicar la plantilla a la muestra de tráileres analizados. 
Se han observado múltiples diferencias en función del genero cinematográfico de la película que cada uno de los tráileres promocionaba, así pues, y comenzando por la música utilizada, destacamos que en los films de acción normalmente se utilizan un máximo de tres temas instrumentales, mientras que en las comedias se utilizan entre tres y cinco temas, y en el caso de los films de terror aparecen múltiples fragmentos musicales aislados. Este uso de músicas está, en las películas de acción, separados por silencios, los cuales ayudan a mantener la tensión de la acción; en el caso del terror el uso de los mismos es habitual, mientras que en las comedias no se observa una generalización en dicho uso.

Respecto a las piezas musicales que aparecen en los tráileres de acción, estas usan una canción preexistente, habitualmente la última de las tres; mientras que en el caso de las comedias todos los temas son preexistentes; y en el caso del terror, al tratarse de fragmentos muy breves, no existe un predominio en este sentido. Si nos centramos en los estilos musicales utilizados en dichas canciones preexistentes, podemos afirmar que tanto los tráileres de acción como los de comedias usan géneros populares modernos como el pop, rock o funk.

Respecto a la métrica y la rítmica, observamos como en el caso de las músicas usadas para promocionar los films de acción usan ritmos binarios a un tempo medio-alto (120-180 bpm); mientras que los tráileres de las comedias usan tempos medios (80$130 \mathrm{bpm}$ ) en ritmos binarios incluyendo, en ocasiones, alguna canción diegética ${ }^{2}$ con ritmo ternario; en el caso del terror, predomina el uso de tempos muy lentos $(<60$ bpm) con pequeñas inserciones contrastantes de ritmos muy rápidos (> $180 \mathrm{bpm})$.

Refiriéndonos ahora a las instrumentaciones usadas, además de las típicas de la música moderna, predomina el uso de sintetizadores en el caso de los tráileres de acción; orquestaciones modernas o clásicas en las comedias; y una combinación de sintetizadores, orquestaciones clásicas y ambientaciones propias del rock gótico en el caso de los tráileres de terror. Por último, en todos los casos, la música usada persigue, principalmente, un efecto empático.

Respecto al ambiente sonoro, podemos afirmar que en el caso de los tráileres de acción predomina un continuo uso de efectos de sonido diegéticos que, habitualmente, sirven para cambiar de secuencia, así como efectos sonoros no diegéticos usados en los cambios de plano y en los créditos; en el caso de los tráileres de comedias predominan los efectos sonoros no diegéticos exclusivamente en los créditos; en cambio, en los de terror, existe un uso generalizado de sonidos diegéticos durante todo el tráiler, acompañados de algún efecto no diegético en los créditos.

\footnotetext{
2 Entendemos por sonido "diegético" aquel que proviene de fuentes que el espectador puede reconocer físicamente en la pantalla, mientras que el sonido "no diegético"-también denominado incidental- sería el que no proviene de fuentes que aparecen en pantalla.
} 
Respecto a la voz, todos los tráileres de los diferentes géneros cinematográficos analizados coinciden en el uso de diálogos de los personajes mezclados con voz en off, la cual, en el caso de los tráileres de acción, muestra especial protagonismo al hacer las funciones de hilo conductor entre las diferentes escenas.

\section{CONCLUSIONES}

Después de lo señalado, podemos afirmar que la música y el sonido en los tráileres es un elemento básico tanto a nivel estructural como emocional. Los resultados muestran como el ritmo de la música se adecua al ritmo del montaje $\mathrm{y}$, en definitiva de la acción, destacando los tempos que incitan al movimiento, tal como vimos en el caso de la acción, o los extremos que producen en el espectador la alternancia entre tensión y relajación propios del terror, marcados por el uso de tempos muy rápidos y en combinación con otros muy lentos.

Por otro lado, hemos observado como la música usada en los tráileres es, en todos los casos, empática con las escenas visuales que acompaña, lo cual no es así en las películas. Sin duda, dicha empatía ayuda a transmitir en el corto espacio de tiempo del que dispone un tráiler el género cinematográfico de la película que promociona.

De la misma forma, destacamos el uso que los montadores de los tráileres hacen de los sonidos diegéticos para suavizar los continuos cambios de plano, así como los no diegéticos para acompañar los títulos de crédito.

Por último, queremos enfatizar la importancia que el silencio tiene en los tráileres y como los montadores, especialmente de películas de acción y de terror, se aprovechan de su uso para ofrecer momentos de incertidumbre e incluso de angustia.

En cualquier caso, tanto el sonido como la música que se usan en los diferentes tráileres objeto de este estudio, atienden a elementos de estilo y estructura, orientando siempre las emociones del espectador.

\section{REFERENCIAS}

Calderón Garrido, C. \& Gustems Carnicer, J. (2012). Fundamentos psicológicos y emocionales del sonido en los audiovisuales. En J. Gustems (Coord.), Música y sonido en los audiovisuales (pp. 49-65). Barcelona: Publicacions i edicions de la Universitat de Barcelona.

Chion, M.(1991). L'audio-vision. Paris: Nathan. Trad. castellana LÓPEZ RUIZ, A. (1993). Audiovisión. Introducción a un análisis conjunto de la imagen y el sonido. Barcelona: Paidós.

Dornaleteche, J. (2007). Definición y naturaleza del tráiler cinematográfico. Pensar la publicidad, 1(2), 99116. 
Gil, E. (2012). La manipulación temporal en los tráileres de cine: articulación de un nuevo tiempo narrativo. Estudios sobre el Mensaje Periodístico, 18, 433441. DOI: http://dx.doi.org/10.5209/rev_esmp.2012.v18.40998

Gustems Carnicer J. \& Calderón Garrido, C. (2014). El análisis multimodal en la escucha de los audiovisuales. En J. Gustems (Coord.), Música y audición en los géneros audiovisuales (pp. 15-28). Barcelona: Publicacions i Edicions de la Universitat de Barcelona.

Iuva, P. O. (2010). A desconstruçao audiovisual do trailer. Em Questão, 16(1), 165-177.

Llinares Heredia, F. (2012). El sonido como recurso expresivo en los audiovisuales. En J. Gustems (Coord.), Música y sonido en los audiovisuales (pp. 135-145). Barcelona: Publicacions i edicions de la Universitat de Barcelona.

Llinares Heredia, F. (2014). La dimensión sonora de los tráileres. En J. Gustems (Coord.), Música y audición en los géneros audiovisuales (pp. 155-167). Barcelona: Publicacions i Edicions de la Universitat de Barcelona.

Marimon, J. (2014). El montaje cinematográfico, del guión a la pantalla. Barcelona: Publicacions i edicions de la Universitat de Barcelona.

Murch, W. (2003). En el momento del parpadeo. Un punto de vista sobre el montaje cinematográfico. Madrid: Ocho y Medio.

Sedeño-Valdellós, A. (2012). Video musical y cultura: propuestas para analizar el cuerpo en el videoclip. Vivat Academia, XIV(120), 91-101. DOI: http://dx.doi.org/10.15178/va.2012.120.91-101 


\section{AUTORES:}

\section{Francesc Llinares Heredia:}

Licenciado en Historia del Arte y especialista en informática musical, es profesor de música en secundaria y de música y sonido en Comunicación Audiovisual en la Universidad de Barcelona. Sus ámbitos de investigación giran, por un lado, en torno a las últimas tecnologías aplicadas a la educación musical y por otro, en torno a la incidencia del sonido y de la música en los medios audiovisuales.

\section{Diego Calderón Garrido:}

Titulado superior en Música Moderna y Jazz, es profesor de comunicación audiovisual y coordinador del posgrado Nuevas Músicas en la Educación de la Universidad de Barcelona, así como director de la Big Band de la misma Universidad. Sus ámbitos de investigación giran en torno al uso de la música en diferentes ámbitos audiovisuales así como el papel que dicha música juega al caracterizar los diversos contextos comunicativos.

\section{Josep Gustems Carnicer:}

Doctor en Pedagogía, titulado superior de música y licenciado en Geografía e Historia. Es profesor de música y sonido en Comunicación Audiovisual en la Universidad de Barcelona, donde es director del Departamento de Didáctica de la Expresión Musical y Corporal de esta universidad. Autor y editor de dos volúmenes dedicados a este tema: Música y sonido en los audiovisuales (2012) y Música y audición en los géneros audiovisuales (2014), ambos publicados por la UB. 